\title{
ANALISIS PENGELOLAAN KOMUNIKASI KRISIS: STUDI KASUS PENANGANAN PANDEMIK COVID 19 OLEH PEMERINTAH PROVINSI SULAWESI TENGAH
}

\author{
Edwan $^{1 *}$, Nurhaidar ${ }^{1}$ \\ ${ }^{1}$ Program Studi Ilmu Komunikasi FISIP Universitas Tadulako \\ *Email: edwan064@gmail.com
}

\begin{abstract}
The spread of the Corona Virus (covid 19) in Indonesia is increasing. Throughout 2020 the number of confirmed positive increases every day to reach hundreds of thousands of people. In Central Sulawesi, the number of confirmed positive fluctuates so that it becomes a serious concern for local governments. In a crisis situation, the provincial government has also taken a number of steps in terms of handling covid 19, especially in minimizing public concerns and anxiety in dealing with the Covid 19 pandemic. Crisis communication facing the Covid-1 pandemic in 2020. At the beginning of the emergence of Covid 19. The results of this study indicate that the Public Relations of Central Sulawesi Province has done a number of things, especially in the pre-crisis, during the crisis and a number of planning steps in the post-crisis. Several steps were taken in accordance with the technical guidelines of the central government and adapted to regional conditions and situations because they do not yet have a standard crisis planning model.
\end{abstract}

Keywords: Crisis Communication; Covid 19 Pandemic; Public Relations;

Central Sulawesi Goverment

\begin{abstract}
ABSTRAK
Penyebaran Corona Virus (covid 19) di Indonesia kian meningkat. Sepanjang tahun 2020 jumlah terkonfirmasi positif bertambah setiap harinya hingga mencapai ratusan ribu orang. Di Sulawesi Tengah, angka terkonfirmasi positif berfluktuasi sehingga ikut menjadi perhatian serius bagi pemerintah daerah. Dalam situasi krisis, pemerintah Provinsi pun telah mengambil sejumlah langkah dalam hal penanganan covid 19 utamanya dalam meminimalisir kekhawatiran serta kecemasan masyarakat dalam menghadapi pandemic Covid 19. Penelitian ini ingin mengetahui bagaimana langkah yang ditempuh oleh pemerintah daerah dalam hal ini Biro Humas Provinsi Sulawesi Tengah dalam pengelolaan komunikasi krisis menghadapi pandemik Covid-1 di tahun 2020. Di awal-awal kemunculan Covid 19. Hasil dari penelitian ini menunjukkan bahwa Humas Provinsi Sulawesi Tengah telah melakukan sejumlah hal khususnya pada pra krisis, saat krisis dan sejumlah langkah perencanaan pada pasca krisis. Beberapa langkah dilakukan disesuaikan dengan petunjuk teknis pemerintah pusat dan disesuaikan dengan kondisi dan situasi daerah sebab belum memiliki model perencanaan krisis yang baku.
\end{abstract}

Kata Kunci: Komunikasi Krisis; Pandemi Covid 19; Humas; Pemprov Sulteng Submisi: 29 Desember 2021

\section{Pendahuluan}

Perhatian masyarakat global saat ini kian intens tertuju pada kasus penyebaran virus corona (coronavirus) atau covid 19 yang semakin meluas. World Health Organization (WHO) pada pertengahan Maret 2020, resmi menetapkan wabah virus corona yang bermula dari Kota Wuhan Provinsi Hubei, Cina tersebut sebagai kasus pandemik (Sumber:Dok Resmi Kemenkes,2019) Pasca penetapan WHO, tercatat jumlah kasus virus corona terus menyebar dengan cepat. Data terkini dari yang dilansir dari www.worldmeters.info 
menyebutkan jumlah terbaru yang telah terkonfirmasi per 24 Maret 2020 mencapai 381.761 kasus pada 195 negara di seluruh dunia. Dari jumlah itu, angka kematian mencapai 16.558 dan jumlah yang berhasil disembuhkan sebanyak 102.429 kasus. Dari jumlah tersebut, Indonesia menyumbang 579 kasus hanya dalam hitungan kurang dari sebulan, dengan jumlah kematian sebanyak 49 kasus dan 30 kasus dinyatakan sembuh.

Respon pemerintah pusat terhadap pandemik ini pun ditindaklanjuti di tiap-tiap pemerintah daerah. Data terakhir diketahui hingga 25 Maret 2020, laporan Pusat Data dan Informasi (Pusdatina) Covid 19 Provinsi Sulawesi Tengah mencatat terdapat 38 orang masih dalam status Orang Dalam Pemantauan (ODP) dan 19 lainnya berstatus Pasien Dalam Pemantauan (PDP). Selebihnya dari 19 PDP tiga diantaranya dinyatakan negatif dan 16 masih proses pemeriksaan laboratorium. Perkembangan penyebaran Covid 19 terus terjadi, sehari setelahnya 26 Maret 2020, Gubernur Sulawesi tengah secara resmi mengumumkan 1 pasien PDP terkonfirmasi positif corona. (Radarsulteng.online). Tercatat, jumlah pasien terkonfirmasi positif termasuk yang berstatus Orang Tanpa gejala (OTG), dan pasien yang berhasil sembuh hingga menjelang akhir 2020 ini terus berfluktuasi.

Sejak pertengahan Maret langkah cepat telah diambil oleh pemerintah daerah, diantaranya dengan dikeluarkannya dengan segera sejumlah surat edaran dan surat keputusan tentang langkah antisipasi dan pencegahan, serta hal-hal terkait lainnya dalam proses penanganan dan penanggulangan pandemik covid 19. Dalam konteks aturan, pemerintah daerah pada dasarnya memiliki acuan Peraturan Menteri dalam bentuk pedoman umum pengelolaan krisis. Hanya saja sampai saat ini pemprov Sulteng belum terlihat mempersempit aturan tersebut ke skala internal pemerintah daerah. Padahal pedoman tersebut masih bersifat umum dan berhak untuk dijabarkan sesuai dengan karakteristik dan tingkat kerentanan isu di tiap wilayah. Terlebih dalam Permen tersebut, belum mengidentifikasi wabah pandemik sebagai salah satu jenis krisis yang wajib diwaspadai. Hal ini memungkinkan aparatur daerah bekerja keras menemukan pola penanganan yang tepat dalam situasi seperti ini.

\section{Komunikasi Krisis}

Komunikasi merupakan bagian penting dalam manajemen krisis. Dalam kegiatan kehumasan, komunikasi mengambil peran nyata dalam membangun hubungan yang baik antara organisasi dan publiknya, terlebih jika organisasi berada ataupun berhadapan dengan situasi krisis. Krisis adalah hal yang tidak dapat dihindari, namun banyak cara yang dapat dilakukan untuk mencegahnya. Diantaranya langkah antisipasi untuk menghindari dampak negatif dari krisis dengan mempersiapkan strategi dan taktik melalui sebuah pengelolaan ataupun manajemen komunikasi krisis yang tepat. Komunikasi Krisis sendiri merupakan suatu rangkaian kegiatan mulai dari tindakan pengumpulan, pengolahan, hingga penyebaran informasi yang dibutuhkan untuk mengatasi situasi krisis yang sedang terjadi (Kriyantono, 2012).

Masih menurut Kriyantono (2012:189) bahwa prinsip pertama dalam manajemen krisis yaitu berorientasi pada keselamatan publik. Public Relations masih menurut Kriyantono, juga menerapkan strategi komunikasi krisis yang dirancang dengan beberapa poin penting dalamnya. Pertama, adalah untuk mengurangi resiko muncul kepanikan publik. Kedua, mengurangi kekhawatiran yang dirasakan publik. Ketiga, mengurangi spekulasispekulasi khususnya di awal-awal krisis. Keempat, melindungi organisasi dari kritikkritik spekulasi, yang biasanya muncul dari diskursus publik di media massa. Kelima, bersifat dapat dipercaya (accountability), keterbukaan (disclosure), dan komunikasi berbasis keseimbangan kepentingan (symmetrical communication), dan Keenam adalah didesain untuk meminimalkan kerusakan pada citra organisasi. 
Menghadapi krisis, diperlukan pemahaman tentang tahapan krisis sekaligus penerapan model manajemen dan komunikasi krisis yang sekiranya akan digunakan. Menurut Coombs dalam Kriyantono (2012:209), tahapan ini dimulai dari tahap Pra-Krisis, dimana akan perlu mengambil langkah manajemen krisis dengan signal detection, prevention, dan preparation. Model komunikasi krisis yang digunakan dalam pra krisis ini harus dikhususkan dengan membentuk pengetahuan tentang krisis (lebih bersifat internal), serta menyamakan persepsi di antara anggota organisasi. Di tahap krisis, perlu untuk mengetahui peristiwa-peristiwa pemicu dan respons, serta damage containment. Dalam tahap ini komunikasi yang dilakukan sebisa mungkin bertujuan untuk memengaruhi persepsi publik tentang krisis, persepsi tentang organisasi dan segala upaya organisasi mengatasi krisis (initial response dan corrective and reaction). Di tahap Pasca-Krisis, adalah proses recovery, learning, follow up informasi dengan publik, kerja sama untuk investigasi, serta berupaya untuk kembali normal. Bagi organisasi, komunikasi krisis dilakukan untuk memuligkan reputasi dan mengembalikan reputasi yang sempat hilang akibat krisis.

\section{Humas Pemerintah}

Humas Pemerintah Berdasarkan Peraturan Menteri Dalam Negeri Nomor 13 Tahun 2011 Tentang Pedoman Pelaksanaan Tugas Kehumasan di Lingkungan Kementerian Dalam Negeri dan Pemerintah 99 Daerah dijelaskan bahwa Humas Pemerintah merupakan aktivitas lembaga dan atau individu penyelenggara pemerintahan yang melakukan fungsi manajemen dalam bidang komunikasi dan informasi kepada publik pemangku kepentingan dan sebaliknya. Adapun Suprawoto (2018:48- 49) menjabarkan bahwa Humas Pemerintah memiliki tugas sebagai perpanjangan tangan dari kebijakan pemerintah untuk menghubungkan interaksi dengan warganya. Berdasarkan dua pengertian di atas dapat disimpulkan bahwa
Humas Pemerintah merupakan suatu bagian dalam pemerintahan yang menjalankan aktivitas komunikasi dua arah antara pemerintah dengan masyarakat untuk menciptakan hubungan yang saling menguntungkan antara keduanya. Dozier dan Broom memaparkan empat peranan Humas dalam menciptakkan hubungan antara instansi dan publiknya (Ruslan, 2016: 20-21), yaitu: (1) Penasihat ahli (expert prescriber), yaitu berperan aktif dalam membantu manajemen dengan cara memberikan solusi terhadap masalah yang dialami organisasi dengan publiknya; (2) Fasilitator komunikasi (communication facilitator), yaitu menjadi mediator antara organisasi dengan publiknya agar tercipta komunikasi timbal balik yang saling menguntungkan. (3) Fasilitator proses pemecahan masalah (problem solving process facilitator), yaitu menjalankan fungsi manajemen dengan berperan sebagai penasihat hingga pengambil keputusan ketika organisasi sedang dihadapkan pada suatu krisis; dan (4) Teknisi komunikasi (communication technician), yaitu berperan sebagai jurnalis dalam organisasinya dan memberikan pelayanan teknis komunikasi kepada publik.

Pengelolaan komunikasi krisis dalam pemerintahan pun selama ini telah diatur dalam Peraturan Menteri Pendayagunaan Aparatur Sipil Negara dan Reformasi Birokrasi (Menpan RB) Republik Indonesia Nomor 29 Tahun 2011 Tentang Pedoman Umum Komunikasi Krisis di Lingkungan Instansi Pemerintah. Melalui peraturan menteri (Permen) tersebut, aparatur pemerintahan diharapkan memiliki kemampuan untuk mengelola komunikasi krisis, baik pencegahan, terjadinya krisis maupun setelah krisis terjadi. Komunikasi Krisis didefinisikan sebagai penyampaian pesan antara instansi pemerintah dan publik untuk menyamakan persepsi dalam penanganan krisis (sebelum, selama dan setelah krisis).(Permenpan RB, 2011). Ada beberapa faktor kunci keberhasilan pengelolaan komunikasi krisis yang sudah digambarkan di pedoman umum tersebut, 
yaitu interaksi awal, komposisi tim krisis, penguasaan krisis, kepemimpinan, dan budaya organisasi. Sekaitan dengan pandemik Covid 19, pemerintah daerah selaku perpanjangan tangan pemerintah pusat harus memiliki kesiapsiagaan dalam menghadapi krisis semacam ini. Pemerintah daerah harus memastikan bahwa seluruh masyarakat mendapatkan informasi yang memenuhi unsur keterbukaan, dapat dipercaya, seimbang dan selalu diperbaharui dari waktu ke waktu. Hal tersebut berguna untuk memenuhi kebutuhan akan informasi yang dapat mengurangi ketidakpastian, kekhawatiran, maupun kepanikan masyarakat yang bisa berlebihan. Kondisi saat ini mengharuskan kelembagaan humas pemerintah dituntut dapat lebih proaktif dan tanggap terhadap isu yang sedang terjadi, serta memiliki kompetensi yang andal dalam melakukan komunikasi krisis kepada publik sebagai sebuah upaya penanganan dan pengendalian.

\section{Konseptualisasi Penelitian}

Penelitian ini menggunakan tipe penelitian kualitatif dengan pendekatan studi kasus. Menurut Creswell (2007: 7374) studi kasus adalah pendekatan kualitatif dimana peneliti menjelajahi suatu atau beberapa kasus dalam jangka waktu tertentu, melalui pengumpulan data yang detail dan mendalam dengan melibatkan berbagai sumber informasi. Penulis mengambil pendekatan ini karena menilai bahwa penelitian ini memiliki kekhususan dan juga urgensi tersendiri. Penelitian ini dilaksanakan di Kota Palu sebagai ibukota Provinsi Sulawesi Tengah, dimana pemerintahan daerah berpusat.

Subjek dari penelitian ini adalah bagian Humas dan Protokol secretariat daerah pemerintah Provinsi Sulawesi Tengah yang berlokasi di Kota palu dengan waktu penelitian sejak bulan Juni hingga Juli 2020. Sumber data primer dari penelitian ini berasal dari hasil wawancara dengan para informan yang sudah ditentukan. Dalam menentukan informan, peneliti menggunakan mekanisme purposif.
Mekanisme purposif artinya menentukan informan sesuai dengan kriteria tertentu yang telah ditetapkan sebelumnya (Afrizal, 2015: 140). Kriteria informan dalam penelitian ini harus merupakan orang-orang yang memiliki pengetahuan atau mengalami atau terlibat dalam kegiatan komunikasi krisis yang dilakukan oleh Biro Humas Pemerintah Daerah Provinsi Sulawesi Tengah. Adapun sumber data sekunder dalam penelitian ini dapat berupa literatur buku, hasil penelitian sebelumnya, pemberitaan media massa, peraturan dan kebijakan pemerintah, press release, foto, lain sebagainya. Dalam penelitian ini digunakan tiga teknik pengumpulan data yaitu: (1) Wawancara semi terstruktur, yaitu jenis wawancara yang dilakukan dengan mengembangkan pedoman wawancara yang telah disusun sebelumnya sesuai dengan situasi dan kondisi untuk mendapatkan data yang lebih lengkap (Kriyantono, 2014: 101102); (2) Observasi non partisipan, yaitu peneliti hanya bertindak sebagai pengamat tanpa ikut terjun melakukan aktivitas seperti yang dilakukan kelompok yang diteliti (Kriyantono, 2014: 112); dan (3) Studi terhadap dokumen pendukung. Teknik analisis data dalam penelitian ini mengacu pada model Miles dan Huberman yang terdiri dari tiga tahap (Pujileksono, 2016: 152; Ghony \& Almanshur, 2016: 307-310), yaitu: (1) Reduksi Data (Data Reduction), merupakan proses untuk merubah dan menyederhanakan data mentah yang didapatkan di lapangan menjadi data yang penting saja; (2) Penyajian Data (Data Display), menyajikan data yang sudah direduksi sebelumnya dalam bentuk uraian singkat, teks naratif, bagan, hubungan antar kategori, gambar, tabel dan sebagainya agar menjadi lebih tersusun dan terorganisir; dan (3) Penarikan Kesimpulan dan Verifikasi (Conclusion Drawing and Verification), kesimpulan merupakan penegasan dari temuan penelitian yang telah dianalisis. 


\section{Hasil Penelitian}

\section{Pandemi Covid 19 di Sulawesi Tengah}

Berdasarkan Pedoman Pencegahan

dan Penanggulangan Coronavirus Desease (Covid 19) revisi ke 5 (2020:20) bahwa Coronavirus Disease 2019 (COVID-19) merupakan penyakit menular yang disebabkan oleh Coronavirus jenis baru. Penyakit ini diawali dengan munculnya kasus pneumonia yang tidak diketahui etiologinya di Wuhan, China pada akhir Desember 2019 (Li et al, 2020). Berdasarkan hasil penyelidikan epidemiologi, kasus tersebut diduga berhubungan dengan Pasar Seafood di Wuhan. Pada tanggal 7 Januari 2020, Pemerintah China kemudian mengumumkan bahwa penyebab kasus tersebut adalah Coronavirus jenis baru yang kemudian diberi nama SARS-CoV-2 (Severe Acute Respiratory Syndrome Coronavirus 2). Virus ini berasal dari famili yang sama dengan virus penyebab SARS dan MERS.

Meskipun berasal dari famili yang sama, namun SARS-CoV-2 lebih menular dibandingkan dengan SARS-CoV dan MERS-CoV (CDC China, 2020). Proses penularan yang cepat membuat WHO menetapkan COVID-19 sebagai KKMMD/PHEIC pada tanggal 30 Januari 2020. Angka kematian kasar bervariasi tergantung negara dan tergantung pada populasi yang terpengaruh, perkembangan wabahnya di suatu negara, dan ketersediaan pemeriksaan laboratorium. Thailand merupakan negara pertama di luar China yang melaporkan adanya kasus COVID-19. Setelah Thailand, negara berikutnya yang melaporkan kasus pertama COVID-19 adalah Jepang dan Korea Selatan yang kemudian berkembang ke negara-negara lain. Sampai dengan tanggal 30 Juni 2020, WHO melaporkan 10.185.374 kasus konfirmasi dengan 503.862 kematian di seluruh dunia (CFR 4,9\%). Negara yang paling banyak melaporkan kasus konfirmasi adalah Amerika Serikat, Brazil, Rusia, India, dan United Kingdom. Sementara, negara dengan angka kematian paling tinggi adalah
Amerika Serikat, United Kingdom, Italia, Perancis, dan Spanyol. Indonesia melaporkan kasus pertama COVID-19 pada tanggal 2 Maret 2020 dan jumlahnya terus bertambah hingga sekarang. Sampai dengan tanggal 30 Juni 2020 Kementerian Kesehatan melaporkan 56.385 kasus konfirmasi COVID-19 dengan 2.875 kasus meninggal (CFR 5,1\%) yang tersebar di 34 provinsi. Sebanyak 51,5\% kasus terjadi pada laki-laki. Kasus paling banyak terjadi pada rentang usia 45-54 tahun dan paling sedikit terjadi pada usia 0-5 tahun. Angka kematian tertinggi ditemukan pada pasien dengan usia 55-64 tahun.

Di Sulawesi Tengah, kasus pertama terkonfirmasi positif pada tanggal 26 Maret 2020 berjumlah dua orang yang semuanya berasal dari Kota Palu. Setelahnya, jumlah terkonfirmasi positif, maupun yang berstatus Pasien Dalam Pengaawasan (PDP) dan Orang Dalam Pemantauan (ODP) terus berfluktuasi. Data Pusat Data dan Informasi (Pusdatina) Covid 19 Provinsi Sulawesi Tengah mencatat, fluktuasi tersebut diantaranya terjadi. Beberapa yang berstatus PDP di jelang April kembali terkonfirmasi positif dan terus ada penambahan pasien dengan status dalam pengawasan. Pertengahan April terkonfirmasi positif sebanyak 22 kasus. Angka per 3 September 2020 dari update data Pusdatina Covid 19 Sulawesi Tengah mencatat, kasus komulatif positif Sulteng mencapai 249 kasus, kasus sembuh sebanyak 221, dan meninggal sebanyak 11 kasus.

\section{Tahapan Penanganan Krisis Humas Pemprov Sulteng Pra Krisis (Pre Crisis)}

Dari hasil penelitian, diketahui pemerintah Provinsi Sulawesi Tengah terbilang tanggap dalam menghadapi kejadian Covid 19 ini. Di awal-awal kasus Covid mulai merebak dan ada di Indonesia, pemerintah provinsi Sulteng juga telah melakukan kesiapsiagaan dengan sejumlah langkah konkrit diantaranya dengan langsung membentuk gugus tugas percepatan penanganan corona di Sulawesi 
Tengah. Surat Keputusan Gubernur dengan nomor 443/131/DIS.KES-G-ST/2020 tersebut memuat sejumlah hal yang berkaitan dengan langkah-langkah yang harus dilakukan oleh semua pihak dalam menghadapi covid 19. Tindakan tersebut sebagaimana hasil kutipan wawancara, juga dilakukan sebagai tahapan penyamaan persepsi antara semua pihak secara berjenjang di lingkungan provinsi Sulawesi Tengah. Dalam SK tersebut dijabarkan beberapa tugas utama dari gugus tugas, diantaranya melaksanakan komunikasi public dengan konten kreatif dan edukasi melalui media massa, sosial media, serta sosialisasi dan kampanye kepada masyarakat terkait langkah percepatan penanggulangan penanganan covid 19 di Sulawesi Tengah.

Tugas tersebut telah disahuti oleh Humas Pemprov Sulteng dengan melakukan publikasi kepada masyarakat melalui sejumlah media lokal, media sosial, dan sosialisasi yang menyertakan sejumlah media luar ruang. Selain itu dilakukan pula komunikasi intens dan berjenjang kepada seluruh PPID di wilayah provinsi Sulawesi Tengah guna percepatan informasi hingga ke tingkat bawah. Hal ini sejalan dengan Model komunikasi krisis yang disarikan dari Coombs dalam Kriyantono ini, secara umum memiliki kesamaan dengan model dari Duke \& Masland (2002), yakni crisis preparedness yaitu memiliki rencana komunikasi untuk antisipasi krisis.

\section{Krisis}

Tahapan kedua dari tahapan krisis adalah tahap krisis itu sendiri. Setelah sebelumnya, pemerintah Provinsi Sulawesi Tengah mulai bersiap dengan berbagai kemungkinan datangnya Covid 19 ke wilayah Sulteng, melalui berbagai langkah yang dianggap sebagai langkah preventif atau pencegahan. Tahap krisis dalam penelitian ini dioperasionalkan sebagai tahapan saat kasus covid 19 terkonfirmasi ada di wilayah provinsi ini. Berdasarkan hasil penelitian, diketahui, Biro humas dan protokoler Sekretariat Provinsi Sulawesi
Tengah lebih mengintensifkan sosialisasi kepada publik secara massive. Hal ini dilakukan untuk lebih mengulik kesadaran diri masyarakat tentang keberadaaan virus ini yang memang nyata keberadaannya. Kesadaran tersebut diharapkan dapat ikut memengaruhi pola keseharian masyarakat dalam melakukan interaksi sosial. Termasuk kesadaran untuk lebih memperhatikan pola hidup bersih dan sebagainya. Humas Pemprov Sulteng dalam melaksanakan fungsinya, tetap memfokuskan diri pada pemberian informasi yang tepat dan cepat kepada masyarakat. "Kami lebih massive lagi dalam sosialisasi, press conference kami lakukan dua hari sekali saat itu, khususnya di awal awal positif corona mulai ada, sekitar tiga bulan, maret, mei dan juni itu cukup gencar,"kata salah satu informan dalam penelitian ini.

Hanya saja, dalam tahapan ini pemerintah provinsi Sulawesi Tengah belum memiliki perencanaan krisis yang menjadi acuan dasar dalam rangka penanganan krisis. Terlihat bahwa yang dilakukan dalam penanganan krisis hanyalah menangani sesuai kondisi yang terjadi. sama halnya ketika provinsi Sulteng melakukan pengelolaan komunikasi krisisnya saat menghadapi bencana gempa bumi, tsunami dan liquifaksi September 2018 lalu. Padahal, sejauh ini Kemenpan RB telah lama mengatur penanganan pengelolaan komunikasi krisis di lingkungan birokrasi melalui Permenpan RB No.29 Tahun 2011 tentang Pedoman Umum Pengelolaan Komunikasi Krisis di Lingkungan Instansi Pemerintah. Bahkan, jajaran humas pemrov Sulteng sebagaimana dari hasil wawancara mengaku belum mengetahui dengan jelas pedoman tersebut.

\section{Pasca Krisis}

Tahapan ini secara teoritis adalah tahapan dimana krisis mulai mereda dan bahkan berakhir. Organisasi dalam tahapan ini sebagaimana dalam Kriyantono ( 2012) adalah tahapan untuk memulihkan reputasi yang mungkin saja sempat hilang saat krisis, selain tahapan pemulihan sekaligus 
pembelajaran bagi organiasasi yang bersangkutan. Dalam kasus penanganan Covid 19 khususnya di Sulteng, tahapan ini belum dilalui sehingga penanganan komunikasi krisis yang dilakukan pun belum mencapai tahapan ini namun masih didasari dengan kondisi krisis yang terjadi saat ini. Meskipun begitu, sejumlah rencana ke depan sehubungan dengan pola pengelolaan komunikasi krisis tengah menjadi pertimbangan tersendiri bagi seluruh jajaran humas di lingkungan setdaprov Sulteng.

\section{Strategi Komunikasi Krisis Yang Dilakukan}

Kriyantono

menggarisbawahi beberapa hal yang menjadi prinsip dasar dalam strategi komunikasi krisis. Beberapa dari prinsip ini juga terlihat dalam komunikasi krisis yang dilakukan oleh pemerintah Provinsi Sulawesi Tengah, meskipun dalam penanganan krisis covid 19 ini pun masih dilakukan secara situasional. Diantaranya;

\section{Memiliki Tim Komunikasi}

Dalam hal ini dapat disebut sebagai tim krisis. Membentuk tim komunikasi atau tim krisis dianggap menjadi satu hal awal yang harus dilakukan dalam penanganan krisis. Tim diharapkan dapat bekerja sejalan, satu presespi dan berkoordasi sesuai dengan tugas dan fungsinya dalam tim. Dalam penanganan covid 19 di Sulawesi Tengah, tim krisis dibentuk dalam satuan tim gugus tugas percepatan penanganan Covid 19 di Sulawesi Tengah. Tim gugus tugas ini meliputi sejumlah unsur terkait diantaranya melibatkan satuan kerja di lingkungan pemerintah provinsi Sulawesi Tengah, unsur Forum Komunikasi Pimpinan Daerah (Forkompimda), serta sejumlah unsur kemasyarakatan yang ada. Tim gugus tugas ini dibagi dalam beberapa pembagian bidang diantaranya bidang akuntabilitas dan pengawasan, bidang humas publikasi dan dokumentasi, bidang perencanaan data pakar dan analisa, bidang operasional, bidang logistic dan bidang pengamanan wilayah. Biro humas sendiri, berada dalam bidang humas publikasi dan dokumentasi dengan tugas utama melakukan komunikasi publik kepada masyarakat terkait Covid 19. Pembentukan gugus tugas ini pula yang menjadi dasar pembentukan Pusdatina atau Pusat data dan Informasi Covid 19 di Sulawesi Tengah dibawah naungan Karo Humas dan Protokol Pemprov Sulteng selaku juru bicara.

\section{Pengelolaan informasi.}

Informasi merupakan produk komunikasi yang semakin urgen dikala krisis melanda. Tidak dipungkiri, masyarakat berhak atas informasi yang akurat dan dapat dipertanggungjawabkan kebenarannnya terkait dengan krisis yang dihadapi. Biro Humas Pemprov Sulteng menyadari hal tersebut dan berupaya memberikan informasi yang semestinya kepada masyarakat sesuai dengan kondisi yang terjadi. berdasarkan hasil penelitian, sejumlah informasi yang selama ini disuguhkan berupa;

\section{Informasi Dasar.}

Informasi dasar mencakup tentang informasi terkait jumlah korban terkonfirmasi positif, ODP, PDP maupun OTG. Termasuk jumlah fasilitas yang digunakan dalam penanganan covid 19 di Sulawesi Tengah. Informasi dasar ini diperbaharui hampir setiap hari melalui berbagai platform media yang ada.

\section{Informasi Imbauan.}

Informasi ini berisi ajakan serta pesan-pesan persuasive kepada masyarakat terkait bagaimana seharusnya masyarakat berperilaku di masa pandemic covid 19 .

\section{Informasi Edukasi.}

Informasi yang berisi tentang pengetahuan kesehatan yang dapat mencegah penyebaran covid 19 termasuk bagaimana pola hidup bersih, pola hidup sehat dan informasi sejenis yang dapat menambah pengetahuan masyarakat. Termasuk informasi-informasi terkini 
terkait dengan kebijakan-kebijakan baru yang layak untuk dipublikasikan kepada masyarakat berkaitan dengan penanganan covid di Sulawesi Tengah.

\section{Informasi Tambahan.}

Informasi ini berupa informasi yang masih berkaitan dengan penanganan covid 19 di Sulawesi Tengah diantara agendaagenda khusus yang dilakukan oleh kepala daerah atau pun pejabat pemerintahan dalam hal penanganan covid.

\section{Penggunaan Media Media Cetak}

Selama ini Biro humas dan protokoler Provinsi Sulawesi Tengah sudah menjalin kerjasama dengan sejumlah media cetak lokal. Kerjasama ini meliputi kerjasama pemberitaan secara berkala terkait program kerja dan kebijakankebijakan pemerintahan yang ada. Dalam masa pandemik covid 19, kerjasama tersebut meliputi pemberitaan perbaruan informasi terkait Covid 19 di Sulawesi Tengah. Diantara media cetak lokal yang turut berperan diantaranya harian Umum Radar Sulteng, Sulteng Raya, dan Mercusuar.

\section{Media Elektronik}

Secara reguler, Biro humas pun juga ikut melakukan kerjasama dengan sejumlah media elektronik khususnya lokal yakni TVRI dan RRI Sulteng, serta sejumlah radio swasta yang mengudara di wilayah Kota Palu khususnya.

\section{Media Online}

Selain menggunakan media massa konvensional seperti koran, televisi dan radio, pemberitaan terkait Covid 19 oleh Biro Humas Pemerintah Provinsi Sulawesi Tengah juga disebarluaskan melalui sejumlah media online di wilayah Sulawesi Tengah.

\section{Media Sosial}

Saat terjadinya krisis, seringkali banyak isu atau rumor terkait krisis pun ikut berkembang. Peran humas adalah harus dapat mengontrol pemberitaan tersebut dengan menyediakan Informasi yang cepat dan tepat. Saat ini media sosial menjadi sarana yang dapat digunakan untuk menyebarluaskan infomasi dengan cepat. Humas pemprov Sulawesi Tengah juga memiliki sejumlah akun media sosial yang juga dimanfaatkan dalam penyebarluasan informasi. Seperti di facebook, instagram, juga media whatshapp.

Dalam menyebarluaskan pesan pesan kehumasan, humas harus mampu menentukan jenis media yang tepat dan efektif (Kriyantono:2018;417). Untuk menentukannya Humas harus dapat melakukan riset terkait efektifitas penggunaan media. Meskipun begitu, dari dampak yang dirasakan, media sosial, berdasarkan hasil wawancara, dianggap paling efektif karena penyebarannya paling cepat serta respon masyarakat pun terlihat.

\section{Media Luar Ruangan}

Tidak semua masyarakat memiliki akses terhadap terpaan media cetak elektronik, maupun media sosial, maka Biro humas pemerintah provinsi Sulawesi Tengah juga menyiapkan media luar ruang yang tersebar di beberapa titik di wilayah Kota Palu dan beberapa titik di wilayah kabupaten sekitar.

\section{Hubungan Dengan Publik}

Berdasarkan hasil penelitian, dirasa perlu untuk melihat bagaiman humas melakukan perannya dalam membangun hubungan baik dengan publiknya. Dalam penelitian ini, peneliti melihat pada dua hal yakni hubungan dengan masyarakat dan hubungan dengan media massa.

\section{Masyarakat}

Masyarakat dalam berbagai kondisi memegang peranan penting dalam hal informasi. Peran masyarakat ikut dibutuhkan dalam hal saran, aduan, ataupun memberikan masukan lainnya terkait kondisi yang terjadi di tengah-tengah 
mereka khususnya dalam menghadapi pandemic covid 19 ini. Dari data yang dikumpulkan diketahui, beberapa platform media yang digunakan memungkinkan Humas mengetahui respon masyarakat terkait pemberitaan yang mereka sebarluaskan. Namun peneliti melihat hal tersebut sebagai hal yang masih harus dilakukan secara maksimal. Artinya tidak sebatas menunggu respon dari komentar atau jenis respon lainnya mellaui media sosial tadi melainkan Humas perlu menyiapkan wadah yang lebih efektif yang secara khusus diperuntukkan untuk menampung aspirasi atau hal hal lain yang menjadi keinginan masyarakat. Ini tidak lain menjadi peran humas untuk menjembatani antara organisasi dan publiknya. Dari wadah tersebut, diharapkan public bukan hanya sekadar merespon tetapi lebih dari itu, publik akan semakin merasa bahwa pemerintah ada untuk mendengarkan. Terlebih situasi pandemic, berbagai masalah di masyarakat bermunculan sehingga humas wajib bersikap jauh lebih peka.

\section{Media Massa}

Media relations adalah salah satu bentuk hubungan yang harus dibangun secara baik oleh Humas, termasuk Humas pemerintah. Di lingkungan secretariat daerah Provinsi Sulawesi Tengah, hubungan dengan media massa dalam hal ini wartawan sudah lama terjalin baik sehingga dengan adanya perubahan kondisi dimana jarak fisik menjadi penekanan yang harus diikuti maka pola interaksi dalam hal media relations juga ikut menyesuaikan. Hal tersebut terlihat di awal-awal kasus covid 19 di Sulteng, pemberlakuan jaga jarak juga dilakukan bahkan beberapa waktu tidak dilakukan pertemuan secara langsung. Wawancara tatap muka dilakukan melalui penggunaan perangkat teknologi maupun internet sebagai contoh melalui grup whatshapp wartawan-humas.

\section{Simpulan}

Hasil dari penelitian ini menunjukkan bahwa Humas Provinsi Sulawesi Tengah telah melakukan sejumlah hal terkait dengan bagaimana mereka mengambil peran dalam hal penanganan Covid 19 di Sulawesi Tengah. khususnya pada pra krisis, saat krisis dan sejumlah langkah perencanaan yang kiranya akan dijalankan pada pasca krisis. Sejumlah langkah diambil sesuai tupoksi dasar dan sesuai arahan dalam tim gugus tugas percepatan penanganan Covid 19 di wilayah Provinsi Sulawesi Tengah, yakni melaksanakan komunikasi publik melalui berbagai pilihan media yang tersedia. Beberapa langkah dilakukan disesuaikan dengan petunjuk teknis pemerintah pusat dan disesuaikan dengan kondisi dan situasi daerah sebab belum memiliki model perencanaan krisis yang baku. Biro humas dalam tugasnya menyebarluaskan informasi terkait Covid 19 di Sulteng tercatat menggunakan beberapa platform media yang dianggap memiliki keunggulan dalam menjangkau publik.

\section{Referensi}

Creswell, John W. 2007. Qualitatif Inquiry and Research Design, Second Edition. California: Sage Publication JComm

Etnografi Kritis dan Kualitatif. Jakarta. Kencana Margono

Kriyantono.2012. Public Relations \& Manajemen: Pendekatan Critical Public Relations

Kriyantono, R. (2014). Teknik Praktis Riset Komunikasi. Jakarta: Kencana PrenadaMedia Group.

Kementerian Pendayagunaan aparatur Negara dan Biroktrasi, Peraturan Menteri Pendayagunaan Aparatur Sipil Negara dan Reformasi Birokrasi (Menpan RB) Republik Indonesia Nomor 29 Tahun 2011 Tentang Pedoman Umum Komunikasi Krisis di Lingkungan Instansi Pemerintah. 
Kementerian Kesehatan, Pedoman

Pencegahan dan Penanggulangan

Coronavirus Desease (Covid 19) revisi ke 5, 2020

Kementerian Kesehatan, Pedoman Kesiapsiagaan Menghadapi Infeksi Novel Corona Virus, 2019

Pujileksono, S.(2016). Metode Penelitian Komunikasi Kualitatif. Malang: Kelompok Intrans Publishing.

Ruslan, R. (2016). Manajemen Public

Relations dan Media Komunikasi:

Konsepsi dan Aplikasi.

Depok:RajaGrafindo Persada.

Surat Keputusan Gubernur dengan nomor

443/131/DIS.KES-G-ST/2020 